\title{
A VIOLÊNCIA COMO DEVIR-SUJEITO EM ALBERT CAMUS, JOSÉ PADILHA E CLARICE LISPECTOR
}

\author{
Lívia Maria Natália de Souza Santos ${ }^{1}$
}

\begin{abstract}
Resumo: O campo das narrativas literárias ou cinematográficas tem a capacidade de refletir sobre problemáticas subjetivas que se contextualizam nas demandas de representação de si. A violência, como desordenadora dos espaços subjetivos, pode funcionar como relevante estratégia de leitura dos domínios do indivíduo, de suas ações e escolhas, das relações com a alteridade e da urgência do devir como um elemento não programado. Este trabalho intenta discutir como as narrativas analisadas empreendem as reflexões mais contemporâneas sobre subjetividade, na medida em que representam o desamparo de personagens em crise.
\end{abstract}

Palavras-Chave: Subjetividade; Violência; Alteridade; Devir.

Resumé: Le champ du récit littéraire ou cinématographique, a la capacité de réfléchir sur des questions qui sont contextualisées dans les revendications subjectives de la représentation de soi. La violence, comme désordre des espaces subjectives, peut fonctionner comme stratégie de lecture important des domaines particuliers de leurs actions et leurs choix, les relations avec l'altérité et de l'urgence de devenir un non-réguliers. Cet article tente d'examiner comment les récits analysés entreprendre davantage de réflexions contemporaines sur la subjectivité, en ce sens qu'il représente l'abandon de personnages en crise.

Mots-clé : La subjectivité; La violence; L'altérité; Devenant.

\section{TÉCNICAS DE CENTRAMENTO: (DE)FORMANDO A NOÇÃO DE SER HUMANO}

Quando, em 1900, Sigmund Freud postula a noção de inconsciente, ele nomeia aquilo que, até então, a religião e as ciências humanas chamavam (numa justaposição de elementos inconciliáveis) de alma, gênio, pneuma, daímon, natureza ou essência. Freud dá uma feição poderosa e altamente indiscriminada àquilo que se move dentro de todos nós, à incontrolável demanda que atravessa a nossa psique e interfere nas nossas formas de ser e estar no mundo. Para além do corpo físico que, segundo os

1 Professora Adjunto do Setor de Teoria da Literatura (DFEL) do Instituto de Letras, Universidade Federal da Bahia (UFBA). Endereço eletrônico: livia.natalia@ufba.br. 
dogmas religiosos, deve se resguardar uma vez que este seria mero invólucro da alma, o pensamento de Freud nos lega o corpo psíquico, um complexo de redes insondáveis através das quais se forma o sujeito. Este sistema controverso teria, para o psicanalista, um governante que alimenta um jogo infinito de esconder-se e disfarçar-se sob a ilusão do domínio e conhecimento de si.

Resistente a qualquer gramática que possa minar a sua capacidade de saturar as expectativas, o inconsciente é um elemento irrepresentável no teatro de si. Enquanto alegoria (BENJAMIN, 1985) que é, ele é constantemente simbolizado, projetando-se num por-vir (DERRIDA, 2003) constante que apenas prenuncia a impossibilidade de deter o fio de seu princípio.

Indo na contramão da visão essencializante do pensamento calcado na metafísica ocidental, a noção de inconsciente, pela partícula negativa que prefixa a palavra, insere a questão de um não controle, de uma não possibilidade de limitação e cálculo e, portanto, de um devir fantasmático que suplanta as anteriores denominações que opunham uma ideia de corpo a outra ideia, a de alma, o ethos ao daímon e assim por diante, revelando a possibilidade da emergência rizomática de elementos não-programados na cena dos afetos do sujeito.

Enquanto contíguo à lógica do rizoma, o inconsciente afasta de si os caminhos óbvios, burla, rouba no jogo, erra nas somas. A memória e a recordação, dois dos mais corriqueiros âmbitos de exercício do inconsciente, são absolutamente reativas à ordem, não são necessariamente assistemáticas, mas renovam continuamente as formas de sua articulação através das incontáveis trajetórias de trilhamento para acesso ao fato lembrado. Ao fim das contas, todos os caminhos para alcançar a lembrança são válidos, verdadeiros, plausíveis e é justamente a pluralidade de verdades autorizadas que oferece à memória e à lembrança o seu caráter rizomático, ou seja, não-originário. Opondo-se à lógica arbórea em que se ordenam os fatos em rotas causais, o rizoma adota como sua norma de funcionamento a deriva:

Uma das características mais importantes do rizoma talvez seja a de ter sempre múltiplas entradas; a toca, neste sentido, é um rizoma animal, e comporta às vezes uma nítida distinção entre linha de fuga como corredor de deslocamento e os estratos de reserva ou de habitação. Um mapa tem múltiplas entradas contrariamente ao decalque que volta sempre "ao mesmo". Um mapa é uma questão de performance (DELEUZE; GUATARRI, 1995, p. 22).

Ao negar a possibilidade de domínio de si, Freud atinge o castelo de cristal da intenção - ideia preciosa durante muito tempo para a crítica 
literária - e finda por desmascarar a naturalização de estratégias muito refinadas de representação de si (FOUCAULT, 2004). As técnicas de escrita e cultivo de uma determinada interioridade ideal e superior à materialidade externa de um corpo, limitado pelos seus excessos e desejos, torna-se, nisto que se convencionou chamar de civilização ocidental cristã, a pauta primeira sobre a qual se formam não apenas os conceitos do que é o "ser humano", como também todas as categorias a ele relacionadas. A própria expressão "ser humano" se ergue numa travessia que pode nos soar incoerente se pensarmos na impropriedade sígnica da articulação do infinitivo ser - que recupera sua raiz essencializante daquilo que é algo, sem negociações possíveis com a transitoriedade do estar ou vinculações positivas com o não-ser - a partícula humano, que se preenche de um significado (e aqui a anterioridade do gesto de enchê-lo de sentido nos é cara), impossibilitando que o nome "ser humano" possa converter-se num gesto de ir sendo, ir existindo.

É neste ensejo que se destaca na discussão deste texto a noção de devir. O termo, vindo do francês devenir traz, em sua composição semântica, a possibilidade de romper a estrutura centrada que sustenta as relações corriqueiras do sujeito logocentrado com o mundo. A vivência enquanto possibilidade, como trajetória não programática e incidental instaura a desordem como lógica de vida. O devir é justamente aquilo que ainda aqui não está, mas que virá a ser, que se tornará, o devir tem no seu bojo a ideia de uma mudança iminente e inescapável. Diferente do porvir que se lança num futuro insondável, o devir denota uma emergência de transformação, a vinda de uma alteridade. Ao formular aqui a noção de devir-sujeito, nos propomos a adensar um tanto as reflexões sobre domínio e consciência de si em contraponto à ideia de que o sujeito é uma construção sempre inacabada. Desta forma, pautados pelo que sinaliza Jacques Derrida em seu texto ainda pouco explorado $O$ animal que logo sou, de 2002, investimos em pensar o devir-sujeito nas personagens centrais do filme Tropa de Elite, de José Padilha; e dos romances $O$ estrangeiro, de Albert Camus e $A$ maçã no escuro, de Clarice Lispector tomando como noção-chave a "rasura do ser". Ou seja, o conceito de indivíduo centrado é deslocado por uma rasura, um borrão, operado na ideia de ser enquanto essência fechada, este movimento, conforme veremos, se dará mediado pelo gesto de violência contra o outro e, em alguma medida, contra a si mesmo e, deste evento se forjará um sujeito desviante, não previsto e não pensado como ideal. 
O conceito aparentemente fechado do que é um ser humano, é um vazio obsessivamente preenchido de sentido que, no entanto, tem a capacidade de mediar as relações interpessoais e definir a quem será ofertada a humanidade. Isto ressoa, por exemplo, nas estratégias biopolíticas (FOUCAULT, 2008) que cumprem seu papel de mantenedoras da vida de alguns e de alheamento permissivo à morte de outros. A noção que estabelecemos de ser humano interfere também nas discriminações várias que sustentam as relações sociais e que servem de sintoma de nossa incapacidade de lidar com aquilo que, no outro, adensa a sua outridade, a saber, a diferença.

A lógica da identidade, egocentrada que é, estabelece um determinado parâmetro centralizador diante do qual os demais são mera diferença e, portanto, hierarquicamente inferiores. Em Nascimento e morte do sujeito moderno, Stuart Hall se dedica ao objetivo de traçar o caminho percorrido por um determinado conceito de "sujeito humano" até a sua emergência pela primeira vez na Idade Moderna. Este conceito condiz com a noção de que o sujeito moderno teria algumas capacidades humanas fixas, um sentimento estável acerca de sua própria identidade, este sujeito estaria em harmonia com uma ordem maior. Objetiva o autor também analisar como este sujeito se tornou "centrado", como esteve ligado a uma definição mais sociológica e interativa e, igualmente, como ele está sendo descentrado na "modernidade tardia". A ideia de que os indivíduos eram centrados em identidades unificadas e coerentes e que agora se encontram absolutamente deslocadas e fragmentadas é, para Hall, uma leitura excessivamente simplista. A noção de um individualismo que se ergue na contemporaneidade não se opõe a uma postura anti-individualista do sujeito moderno. $O$ que se modifica é a forma de configuração do ser e estar na modernidade; e esta se forja quando se revelam as maquinarias extremamente humanas sob os conceitos pensados como nascidos de determinações divinas, como consequência, há um distanciamento do indivíduo de tradições e estruturas que o sustentavam e a emergência da noção de um "indivíduo soberano":

As categorias de sujeito, de autor, de indivíduo, etc., são afinitárias de um trabalho de disciplinação do corpo próprio, e nesse processo a escrituração da vida, mas também do corpo, todos os procedimentos de biografização são absolutamente decisivos (FOUCAULT, 1992, p. 30).

Neste ensejo, esta forma de compreender as relações do sujeito com o mundo é atravessada por uma proposta de compreensão distinta nos modos de construção e representação de si. Muitas vezes a capacidade de 
múltiplas inserções sociais, políticas, culturais e pessoais do indivíduo dirigiram o pensamento para a crença de que, neste contexto, haveria uma perda da humanidade: Foucault, Derrida e Nietzsche foram acusados, entre outras coisas, de anti-humanismo, por apregoarem a morte de uma determinada conformação do sujeito. Estes pensamentos nos direcionam a refletir que é a própria noção de indivíduo que precisa ser reavaliada, uma vez que as suas relações com o mundo se modificam rapidamente.

Nesta cena, em que emerge a representação de si como um artifício estruturante de todas as relações, inclusive da pessoa consigo mesma, a emergência do inconsciente pode ser pensado como um dos gestos inauguradores do sujeito - em todas as suas complexidades e incoerências - em franca oposição à noção de indivíduo enquanto um ser pleno a si, centrado e previsível. $O$ indivíduo, indiviso que é, não estabelece fronteiras íntimas entre o conhecido e o inesperado. Não sabe da tensão que perpassa as vésperas do ser não-programático, não conhece os limites que, tênues, o sobrelevam em travessia constante no mundo.

Se a psicanálise e os movimentos de minorias afirmam a potência desaglutinadora das diferenças e também a marca subjetiva inscrita em cada travessia, a literatura e o cinema, por seu turno, muito se dedicaram a equacionar esta demanda, este outro, no campo das subjetividades e representações.

\section{CENA E TEXTO: AS FORMAS DE SER OUTRO}

São muitas as formas de pensar o sujeito na literatura, a exemplo do devir atormentado do fantasma do pai que se arrasta desde Édipo Rei a Antígona enquanto miasmía, uma herança indesejada e malfazeja deixada por Laio a Édipo e por ele a seus descendentes ao Hamlet pai, espectro não previsto nos dogmas do cristianismo ao qual, recentemente, havia sido convertido o Hamlet filho e que enseja a pergunta-chave de toda a ação dramática do "ser ou não ser", indagação inaugural de uma qualidade de heroi indeciso, paripatético, desfibrado. No cinema encarna-se de maneira definitiva a metáfora da travessia e, neste ensejo, este heroi problemático, que se pode ver nas tragédias clássicas ${ }^{2}$, será reconfigurado com inúmeras

2 É importante destacar que nas tragédias o heroi é um problema para si mesmo e para toda uma forma de compreensão de cidadania e de vida em comunidade. Caindo sempre do mais alto ao mais baixo o heroi trágico, a exemplo do Rei Édipo, converte-se em um 
faces na cena da narrativa fílmica. Estas representações do heroi enquanto problema força os limites do conceito de heroísmo e pode ser encontrado desde o suspense do diretor inglês Alfred Hitchcock até a violência da fílmica de Quentin Tarantino. O argumento do sujeito em crise é muito caro à narrativa fílmica, desta forma a pergunta do jovem Hamlet ecoa na formatação da personalidade de inúmeros personagens do cinema. Da mesma forma, o argumento da travessia, como grande narrativa na qual se conta a história do heroi, comparecerá no cinema, apesar de ter, no que tange à representação, como nascedouro, a literatura. $O$ grande arquétipo da travessia é a de Ulisses, que encontra correspondentes mais problemáticos em Dante, que carece do amparo de Virgílio a fim de que possa, ao passar pelo inferno, purgatório e paraíso em busca de sua Beatrice, interpretar o sentido da travessia e, finalmente, Quixote, que acompanhado de guia menos nobre, o aldeão Sancho Pança, e de sua própria loucura, procura por Dulcineia, grande alegoria de sua outridade inalcançável. No entanto, enquanto a literatura utilizará para a construção da sua narrativa elementos básicos como narrador, personagem, espaço, tempo e enredo, o cinema busca extrapolar estes limites conduzindo a sua capacidade de síntese por um caminho longo e populoso de elementos que passeiam desde as obscenas do roteiro, da pré-produção, da seleção de atores e de locações até aqueles elementos que se colocam à vista do público, como a câmera que narra a ação através do enquadramento, a construção da noção de cena, a luz, o figurino, a música, dentre outros inúmeros artifícios.

No filme, o grande conflito mediador ou disparador da travessia do heroi deve se resolver em cerca de $190 \mathrm{~min}$. Seja um problema fundante do sujeito, como nas narrativas de lastro psicanalítico, seja um jogo de eternos descompassos, como os que se vêem nos filmes de Woody Allen, o conflito que se trama na película deverá encontrar um apaziguamento, ainda que este venha no tradicional "I Will be back" que percorre muitos filmes de terror ou nas inúmeras continuidades, representadas com distinção na série de filmes d'O Poderoso Chefão.

O cinema brasileiro recente - notadamente desde Cidade de Deus, em 2002 - tem tomado como espaço privilegiado onde se contextualizam

exemplo do que o cidadão não deve fazer, caso queira continuar no convívio dos demais e em harmonia com os deuses, uma vez que a tragédia mais que representar cenas, alegoriza a vivência dos sujeitos no tecido social (Cf. VERNANT, 1977). Desta forma, a comparação aqui guarda as proporções de diferença entre a problemática que envolve estas duas formas de heroísmo. 
os problemas do sujeito a periferia das grandes cidades. Proliferando-se alucinantes como úlceras multicoloridas e polifônicas, as favelas, assim chamadas desde meados século $\mathrm{XX}$, emergem no corpo acidentado das grandes cidades. Elas servem para nos comprovar que a anatomia das metrópoles é não apenas delimitada pelas suas bordas comumente rasgadas por uma arquitetura desarmônica, mas também se destacam, na sua pele clara de edifícios, a superveniência das diferenças, as marcas de uma cidade outra, longe das ruas planificadas, asfaltadas e numeradas, uma altercidade tecida, entretanto, na mesma malha, com os mesmos fios. Esta diferença é marcada em narrativas como Cidade de Deus, Carandiru, Salve Geral, Cidade Baixa e Ó paí, ó pelas referências diretas às hierarquias sociais que estabelecem limites entre o morador do morro e do asfalto. Tal questão encontra em sua base, conforme se vê nestes filmes, a diferença racial que apenas se hiperboliza ante as distâncias econômicas.

Ambientadas nas favelas cariocas, paulistanas, nos becos acidentados do Pelourinho ou na Cidade Baixa, nos filmes circula uma sensação de cor local que parece exteriorizar os conflitos para além da malha subjetiva. No campo da representação cinematográfica, os estereótipos muitas vezes se reforçam entre tiros, muito sangue e sujeitos em labirintos invencíveis. As demandas são sempre urgentes, jogam com a precipitação trágica e o flerte com o risco impõe uma velocidade lancinante a algumas narrativas, como na primeira cena de Cidade de Deus (Fernando Meirelles, 2002), na qual, como uma cobra que morde a própria cauda, Buscapé é representado na galinha que corre inutilmente, vez que virará o churrasco do "samba de laje" e, ao mesmo tempo, na cena quase final do filme, quando ele se vê encurralado entre a polícia e o bando de Zé Pequeno. $O$ aparente apego à narrativa do mundo de violência e pura intensidade se esmaece quando flagramos a marca da primeira pessoa, na voz do personagem principal, contando a sua travessia que não é apenas a história de um jovem tentando escapar da criminalidade, mas narra a travessia de um sujeito em formação, em suas escolhas e possibilidades. $O$ recurso da narrativa em primeira pessoa suaviza a visão que privilegiaria a cena geral da periferia em sua pulsão destrutiva e derrama importância para o sujeito que narra o seu percurso, que diz de si e que se representa no tecido que conta. Isto se vê nas falas dos presos de Carandiru (Hector Babenco, 2003), que ao narrarem suas vidas não apenas retomam o estatuto da humanidade - comumente em descrédito no espaço das prisões - , mas também reeditam e reinterpretam os fatos. 
O investimento em explorar a dimensão humana de corpos violentos e de repensar a dimensão humana da própria violência inclusive enquanto pulsão de vida encontrará em alguns filmes uma força exemplar. O Última parada 174 (Bruno Barreto, 2008) conta a história de Sandro, sequestrador de um ônibus no Rio de Janeiro, que foi transmitida ao vivo através das câmeras de televisão e culminou com a morte de uma refém e assassinato de Sandro pela polícia. No contexto do filme, a ação violenta será ensejada na órbita de uma infância cercada de mortes - a primeira delas a da mãe e, depois, dos companheiros da Igreja da Candelária - e, finalmente, mostra-se o processo de formação de um devir agressivo num sujeito inicialmente cordato e mediano. Salve geral (Joaquim Vaz de Carvalho, 2009) narra o difícil relacionamento entre Lúcia e Rafael, mãe e filho, que, na teia dos desencontros afetivos destes dois sujeitos e na iminência da incapacidade de lidar com a diferença do outro, vêem-se envolvidos num problema ainda maior, a prisão de Rafael acusado de assassinato justamente durante o Maio de 2006, quando a facção criminosa Primeiro Comando da Capital (PCC) ordena ataques a toda cidade de São Paulo. O jogo entre vida e morte, acionado durante toda a narrativa, encontra seu ápice na paixão vivida entre Lúcia e Professor (um chefe de quadrilha) e sua face mais lírica na fome expressada por Rafael, já fora da cadeia, na cena final.

No cinema que representa a periferia baiana, a saber, ó paí, ó e Cidade Baixa as representações dos sujeitos em travessia e que se deparam com diferenças desordenadoras se adensam. Mais focado no discurso do preconceito racial e econômico, ó paí, ó (Monique Gardenberg, 2007) encena o cotidiano ambivalente dos moradores de um sobrado no bairro do Pelourinho, em Salvador, Bahia. As diferenças de posturas, crenças e histórias de vida - mostrada em muitos momentos como inconciliáveis - são sanadas quando invade a cena a morte de duas crianças. Cidade Baixa, mais centrado na metáfora do título, traz para sua discussão os afetos que circulam no baixo, nos breus, nos sujos, nas dobras das personalidades através do sexo e da violência. O laço fraterno que une Deco e Naldinho se enfraquece quando estes conhecem Karina, uma prostituta que passa a namorar ambos os amigos obedecendo, talvez sem perceber, a dinâmica da partilha e da profunda identificação que une os dois. Deco e Naldinho descobrem um no outro um devir violento, guiado pelo ímpeto da preponderância sobre o corpo de Karina; no entanto, é a cena final - quando, após uma briga intensa, uma bacia de água límpida, vai se turvando do sangue dos dois que expõe a força da ligação destes dois homens: opostos complementares. 
O que está em destaque todo o tempo é a forma como estes sujeitos lidarão com a dor, a violência, a privação de liberdade e, mais ainda, com as relações interpessoais, com as diferenças e as outridades.

O outro sempre será um problema a ser, em alguma medida, solucionado, seja na busca do apaziguamento amoroso através do reencontro com a amada, seja na procura, ainda mais trabalhosa, da compreensão do devir-outro, no campo da sua própria subjetividade estabelecendo como território da travessia aquilo que se convencionou chamar de "eu". Aqui se destacam desde os labirintos borgeanos, passando pelas memórias extemporâneas, porque póstumas, representadas por Machado de Assis no Brás Cubas, a alguns textos em que esta questão se estreita mais fortemente, como em muitos volumes da literatura contemporânea que, propositadamente, virá marcada pelas muitas diferenças, a exemplo das etnicorraciais e de gênero.

O que nos interessa aqui, no entanto, é a forma como esta reflexão aparecerá na escrita de autores como Kafka, que levam a travessia subjetiva de encontro-confronto com o outro ao extremo. Notadamente quando este outro que se descobre não se encontra no espaço fora do próprio sujeito. Toda a travessia na qual investimos até agora buscou lançar algumas reflexões sobre a formação da subjetividade usando como atalho a exploração da ideia de que o sujeito não é jamais um ser apaziguado em si, uma vez que todo processo de construção de subjetividades engendra-se a partir de um intricado jogo de negociações que tem como contexto mais primeiro a infância, nas relações estabelecidas no núcleo familiar mínimo pai-mãefilho/a e se reedita e atualiza nas demais relações do indivíduo em sua história pessoal. Em todo percurso o que está em pauta é como este sujeito irá conviver e relacionar-se com as diferentes alteridades experimentadas no decorrer de sua vida e com a alteridade mais desconfortante, aquela mediada e produzida a partir do inconsciente do próprio sujeito: a alteridade inerente a ele mesmo, que podemos chamar de devir-sujeito.

\section{SUJEITOS ÁRIDOS: A VIOLÊNCIA COMO DEVIR}

O estudo das narrativas que são o foco da discussão aqui proposta, a saber, $O$ estrangeiro (OE), de Camus; Tropa de Elite (TE), de José Padilha e $A$ maçã no escuro (AME), de Clarice Lispector pauta-se na análise da travessia subjetiva de três homens - Mersault, Matias e Martin - todas elas cortadas pela violência como disparador da ação, como em Martin e Mersault, Cláudio Cledson Novaes, Fernanda Aguiar C. Martins, Roberto H. Seidel (Org.) 39 
ou a capacidade de cometer o ato de violência como sendo o ápice da travessia, como no caso de Matias. Em todos os casos, os personagens expõem as suas dificuldades em estabelecer relações com o universo que os cerca, mas, ainda mais definitivamente, com o devir-sujeito que deles emerge e que se apresenta e representa nas relações interpessoais. Todos eles patinam na construção da consciência de que para eles mesmos e também para os demais sujeitos há algo de insondável em sua personalidade, algo não programado e fora de controle que se expressa através da mediação da violência.

Numa primeira mirada, a escolha dos dois romances deriva do fato de os seus protagonistas, Meursault (OE) e Martin (AME), navegarem num aparente vazio interior. O primeiro comporta-se como mero narrador de sua vida, rompendo, por exemplo, com aquilo que a teoria da narrativa prega sobre a parcialidade do narrador de primeira pessoa. E o segundo, Martin, adentra num projeto de recuo subjetivo tão intenso que imagina abdicar não apenas das palavras e de tudo o que elas substituem e simbolizam, mas também do estatuto da linguagem. Ambos parecem ser sujeitos à deriva, alheios de si e do mundo, alienados de um sistema de representação e de convenções sociais; entretanto, o que buscarei discutir aqui é a capacidade que têm estes personagens de, recém-saídos de certo "merguIho introspectivo", em lugar de trazerem, quando ressurgidos à tona, a certeza profunda do que são e de sua função no mundo, retornam com as mãos vazias, como quem, iludido com o espelho d'água, julgou haver espaço para nado na poça que apenas seria capaz de sustentá-lo de pé. Num outro sentido, Matias (TE) empreende uma caminhada em direção ao silenciamento de si, ao apagamento da dimensão humana através da introjeção da capacidade do ato de violência. O que Martin, Matias e Mersault nos demonstram é que o sujeito se forma no e pelo discurso: seja ele o efetivamente proferido, o esperado pelos outros ou ainda aquele que está em processo de construção. Assim, eles nos servem como fértil campo de exemplificação das palavras de Foucault quando afirma que "a profundidade não passa de uma ruga na superfície".

Como textos publicados no século XX, O estrangeiro, em 1942 e $A$ maçã no escuro, em 1956, podemos afirmar que estes romances prenunciam algumas reflexões que se tornarão, a partir da década de 60, não apenas demandas relevantes, mas eixos ordenadores de muitas discussões que balizaram o que, aqui, concordo em chamar de pós-modernidade. A narração da história das personagens é permeada pelos antecedentes de um 
crime, no caso de Meursault, e pelas consequências deste, na história de Martin. Na cena subjetiva destes personagens, mais que qualquer princípio cristão ou legal que engendre a condenação pelo ato criminoso, destaca-se o ato, o gesto desruptivo de violar o princípio último da humanidade que é o de preservação da vida.

Em $A$ maçã no escuro Martin é um homem de meia-idade que se encontra em fuga. A princípio, ele foge de um sistema limitador de vivência e compreensão de mundo, não da autoridade constituída. Ao investir num recuo peremptório de um indivíduo centrado para um si indistinto e indefinido, Martin abdica do seu lugar entre os seres humanos, limita-se ao primeiro termo da nomenclatura e intenta encontrar-se no âmbito dos "seres", do "algo", da "coisa": "Martin mergulhou de novo na mesma ausência anterior de razões e na mesma obtusa imparcialidade, como se nada tivesse a ver consigo mesmo, e a espécie se encarregasse dele" (AME, p. 18). Optando pela escuridão e pelo silêncio, ele estabelece relações heterodoxas com objetos, cheiros, sensações, e com a própria noção de vida, aqui representada pela natureza, em suas dobras mais delicadas, e com os animais. Uma vez pronto para uma nova fase de sua construção, o personagem se representa, não por acaso, como um engenheiro e consegue emprego num rancho na qual moram duas mulheres, a cruel e recalcada Vitória e Ermelinda, dependente e vulnerável. Morando boa parte do tempo no curral e alimentando o próprio silêncio e uma relação imaginariamente imediata com a natureza, Martin investe numa anamnese quase totalmente destituída de expressão verbal buscando compreender quem é, o que é e por que se encontra ali. No entanto, antes ainda, cabe a ele redefinir o seu percurso e o seu modo de estar no mundo, o que ele faz paulatinamente: "Ele que não tinha uma palavra a dizer. E que não queria falar nunca mais. Ele que deixara em greve de ser uma pessoa. No seu terreno, ali sentado, ficava gozando o vasto vazio de si mesmo" (AME, p. 82). Quando finalmente emerge a desconfiança de que há um sistema ao qual as demais pessoas pertencem, uma necessidade de dar utilidade às horas para além da mera contemplação, uma importância no valor que se dão aos gestos e o corpo apela, pelo caminho do sexo, que é também uma gramática instituída, que ele se insira no mundo, Martin inicia o seu retorno. Aos poucos, vai dandose conta de uma lacuna que é - segundo o discurso psicanalítico - estruturante de nossa psique e, através da fome, este homem constroi uma reentrada no universo dos demais homens e mulheres e, uma vez saciado, outras lacunas aparecem e, com isso, vem a consciência do crime: 
Até que nessa tarde na encosta Martin começou a se justificar. Chegara o duro tempo de explicação.

Ali, antes de prosseguir, ele devia ser inocente ou culpado. Ali ele tinha que saber se sua mãe, que jamais o entenderia se fosse viva, o amaria sem entendê-lo. Ali ele devia saber se o fantasma do seu pai lhe daria a mão sem espanto. Ali ele se julgaria - e dessa vez com a linguagem dos outros. Agora teria que chamar de crime o que fizera. $O$ homem estremeceu com medo de tocar errado em si, ele que ainda estava todo ferido (AME, p. 129).

Esta consciência de si, na qual Martin adentra de chofre, certamente não deixou de estar ali, à orla desta construção empírica na qual ele investe durante toda a história. Poderíamos compreender todo este caminho que ele percorre como sendo uma incapacidade imobilizante de narrar um trauma, uma perda de qualquer via de autoridade de relato derivada de uma violência de registro tamanha a ponto de sua máquina cerebral precisar receber um restart, ser como que reiniciada para que as coisas pudessem voltar a ter algum sentido. Sobra a Martin, enquanto experiência subjetiva, a narrativa possível, viável após um trauma desestruturante, a saber, o assassinato de sua esposa.

Na nossa leitura não cabe seguir as perigosas pistas oferecidas por Clarice Lispector em seu encantamento pela capacidade significadora da palavra nem tampouco ceder ao seu desejo de sublimá-la, ideias recorrentes em muitos de seus textos, uma vez que, já nos adianta Derrida, estamos sustentados por uma estrutura fono-logo-etnocêntrica na qual o discurso inclusive enquanto fundador de verdades - ocupa uma função inescapável (DERRIDA, 2002). A forma de conhecimento e de produção dos sentidos delimitados sobre os quais construímos as relações sociais encontra o seu alimento no discurso, e ele estipula os espaços hierárquicos a serem ocupados pelos desiguais. Por isso podemos afirmar que toda a travessia não simbólica, não hermenêutica e não verbal de Martin sustenta-se numa ilusão de exterioridade impossível, uma vez que não existe um fora do pensamento, nem um fora da linguagem.

A noção de estranhamento pode nos ser útil para compreender todo processo de representação de si atravessado pelo personagem no sentido do unheimlich freudiano (1919). O trauma de ter assassinado a esposa gera para o personagem um excesso de estímulo emocional e, graças a isto, ele adentra num processo de estranhamento das formas convencionadas de existência. Este processo atinge o estatuto do "ser humano" em seu bojo: na linguagem e na formação do pensamento. Não preciso aqui avançar no sentido de afirmar a arbitrariedade de toda mecânica de atribuição de sen- 
tido e valor imanente às articulações entre signo, significante e significado (SILVA, 2007) para que se possa compreender que estes processos de estranhamento pelos quais passa Martin são relevantes para o início de qualquer discussão sobre as demandas relativas aos sujeitos, às subjetividades e suas diferenças. Finalmente ele descobrirá que sua esposa sobreviveu à tentativa de assassinato, mas, diante disto, surge outra pergunta para Martin: se não sou eu um criminoso, então o que eu sou?

Deste mal não padece Meursault. Ele simplesmente não se indaga. A sua vida é comezinha, e constitui-se num fluxo quase tão automático quanto o gesto de narrar. Ele também se vê enredado num assassinato, a narrativa que ele apresenta por si já nos sinaliza um ímpeto latente de violência, desde a cena do enterro da mãe - na qual a presença de um sol recalcitrante tortura o personagem - passando pelo vizinho Salamano e seu cão, até a agressividade de Raimundo e o assassinato do Árabe. Assim como n'A maçã no escuro este índice de obscuridade irá, quando não cegar, limitar a visão do protagonista, n'O estrangeiro a grande alegoria é a da luz, vinda, na maioria das vezes de um sol impiedoso e, sob esta iluminação árida e inegociável, Meursault irá desenhar a sua vida com uma precisão e detaIhamento tão sistemáticos a ponto de termos a impressão de que ele ficara cego pela luz.

Tudo o que é dito no romance nasce de uma primeira pessoa marcada por uma inscrição subjetiva que rompe com a norma de um sujeito parcial, passional e auto-piedoso. Não há, para o personagem, via possível de apelo à auto-preservação ou à auto-comiseração. Na cena do julgamento, quando afirma que não chorou no sepultamento da mãe, como também diz não amar Maria, apesar de poder casar-se com ela, não fazer questão da amizade de Raimundo, não obstante a sua aderência preguiçosa aos seus pedidos, compreendemos que Meursault vê a vida a partir da ótica do "tanto faz", insistentemente citado em suas falas. Mais do que qualquer direcionamento no sentido cristão da temperança ou, por outro turno, de uma lassidão injustificada, ele sabe que, no final das contas, tanto faz mesmo.

A ideia de que somos seres especialmente talhados para isto ou para aquilo, que temos uma flama, uma essência divina jamais casaria com o olhar agnóstico de Meursault. E podemos pensar neste olhar como disseminado sobre todo o mundo, uma vez que ele simplesmente optou por não acreditar ardorosamente em nada, por deixar a vida, num fluxo, constituirse. Ele tem uma apatia orientada diante das coisas. A postura de Meursault nos lembra os versos de Alberto Caeiro, sem, no entanto, ceder em nada ao 
encantamento do poeta diante do mundo: "Há metafísica bastante em não pensar em nada", afinal "O único sentido íntimo das coisas/ É elas não terem sentido íntimo nenhum". Há apenas uma coisa que o incomoda e que aparecerá na narrativa como um elemento oportunizador das precipitações: o sol. Apenas o confronto constante entre o sol e a cabeça: "Não pensava em nada, porque estava meio adormecido com todo este sol na minha cabeça descoberta" resultava sempre num grande desconforto e desorientação, quase mais nada o movia, nem a morte, nem os amores, nem qualquer apetite para o que convencionamos compreender como vida:

Quando Raimundo me deu o revólver, o sol refletiu-se na arma. Ficamos imóveis, como se tudo se houvesse fechado em nossa volta. Olhávamo-nos sem baixar os olhos e tudo aqui se detinha entre o mar, a areia, o sol, e o duplo silêncio da flauta e da água.

Pensei neste instante que disparar ou não disparar, era tudo o mesmo (CAMUS, 1957, p. 32).

A cegueira de escuridão buscada por Martin opõe-se à cegueira de Meursault, entretanto, ambas são formas de alterar o modo convencional de ver as coisas. Enquanto a primeira oportuniza uma aprendizagem distinta, a outra desconcentra, mobiliza. Apenas quando tem o seu raciocínio turvado pela luz é que Meursault desencaminha-se. Se o breu metaforiza a busca de par-e-passo alcançar a luz no romance de Clarice, Camus representa na luz a única forma inescapável de escuridão:

A ardência do sol queimava-me as faces e senti o suor amontoar-se-me nas sobrancelhas. Era o mesmo sol do dia em que a minha mãe fora a enterrar e, como então, doía-me a testa, sobretudo a testa e todas as suas veias batiam ao mesmo tempo debaixo da pele. Por causa desta queimadura que já não podia suportar mais, fiz um movimento para frente. Sabia que era estúpido, que não me iria desembaraçar do sol, simplesmente por dar um passo em frente. Mas dei um passo, um só passo em frente.

E desta vez, sem se levantar, o Árabe tirou a navalha da algibeira e mostrouma ao sol. A luz refletiu-se no aço e era como uma longa lâmina faiscante que me atingisse a testa. No mesmo momento, o suor amontoado nas sobrancelhas correu-me de súbito pelas pálpebras abaixo e cobriu-as com um véu morno e espesso.

Os meus olhos ficaram cegos, por detrás desta cortina de lágrimas e de sal. Sentia apenas as pancadas do sol na testa e, indistintamenta espada de fogo brotou da navalha, sempre diante de mim. Esta espada a arder corroía-me as pestanas e penetrava-me nos olhos doridos. Foi então que tudo vacilou. 0 mar enviou-me um sopro espesso e fervente. Pareceu-me que o céu se abria em toda a sua extensão, deixando tombar uma chuva de fogo. Todo o meu ser se retesou e crispei a mão que segurava o revólver. $O$ gatilho cedeu, to- 
quei na superfície lisa da coronha e foi aí, com um barulho ao mesmo tempo seco e ensurdecedor, que tudo principiou.

Sacudi o suor e o sol. Compreendi que destruíra o equilíbrio do dia, o silêncio excepcional de uma praia onde havia sido feliz. Voltei então a disparar mais quatro vezes contra um corpo inerte onde as balas se enterravam sem se dar por isso.

E era como se batesse quatro breves pancadas à porta da desgraça (CAMUS, 1957, p. 34).

A violência do sol nesta cena paradigmática, será, em alguma medida, retomada no recente cinema brasileiro no filme Tropa de Elite. Na história, mais uma vez, tem-se um sujeito em travessia de si para si, numa busca de compreender e localizar os instrumentais através dos quais ele se transformará num outro ele mesmo, ou seja, de aspirante a policial do Batalhão de Operações Especiais (BOPE). A ascensão hierárquica dependerá diretamente da capacidade de dominar o outro - inclusive aquele que "dentro" dele habita - pela violência. O perfil de Matias destoa dos demais aspirantes: ele não é corrupto, nem agressivo. Tem uma postura cordata e tolerante, um negociador nato que - em sendo policial - adentra a favela em vários momentos da narrativa como estudante de direito e convive, tanto na universidade, quanto na comunidade que frequenta, com o tráfico e consumo de drogas. Quando os colegas descobrem a sua profissão, ele ainda tenta continuar convivendo nos mesmos espaços, apesar de ser, ago$\mathrm{ra}$, hostilizado e ridicularizado. $\mathrm{O}$ que chama atenção no comportamento de Matias é a sua inação, seu espírito compassivo e apaziguador apesar das adversidades instaladas nas suas relações tanto na polícia quanto na universidade.

Quando o seu colega de corporação e grande amigo Neto é assassinado em seu lugar, toda a compleição de personalidade de Matias se modifica. Ele imediatamente se vê entranhado numa gramática subjetiva de violência e agressividade aparentemente inconciliáveis com o seu perfil cândido. Esta transformação, guiada pelo devir outro, pela potência de violência latente em sua personalidade, será completa na cena em que o Aspirante Matias é promovido à policial do BOPE. Ali, investindo num interrogatório absolutamente alheio a qualquer norma dos Direitos Humanos, diante do traficante alcunhado de "Baiano", Matias porta uma arma de grosso calibre. $\mathrm{O}$ que Matias busca é a confirmação de que foi este o assassino de seu amigo. Diante da inescapável verdade, Matias recebe a ordem de executar o suspeito. Baiano apela que o aspirante não atire no seu rosto a fim de "não estragar o velório", Matias está pressionado pela necessidade 
de impor-se, pelo sentimento de vingança por ter sido o Baiano o assassino de seu amigo, e cego pela luz que adentra a cena e se coloca entre o cabo brilhante da arma e a face desesperada do traficante, nós, a audiência, ouvimos apenas um forte estrondo e imediatamente compreendemos, pela música de fundo que encerra o filme, que Baiano seria enterrado em caixão fechado. Meursault, no entanto, não tem nenhum destes motivos que Matias teve, nem tampouco qualquer suspeita, como ocorrera a Martin acerca da infidelidade de sua esposa. Diante dele vigorava apenas a violência do sol e a cegueira: tudo vacila, o gatilho cede e o equilíbrio é rompido.

Martin, Matias e Meursault nos sinalizam que tudo é construção e que o maior desafio do sujeito é equacionar e interpretar as diferenças que constituem os outros que formam aquilo a que chamamos eu. $\mathrm{O}$ envolvimento emocional, virulento e instintivo com a sua própria vida, o investimento em importar-se com o futuro e as possibilidades de ser, as projeções das frustrações ao inominado, ao imponderável divino e a defesa quase paralisante de uma essência apaziguadora das inseguranças dos outros que moram em nós, são posturas convencionais para o indivíduo saudoso de um centramento que lhe ofereceria uma ancoragem estável. Na contramão disto, os personagens aqui tomados para análise arriscam-se no sem sentido, no desconhecido e, através da capacidade de matar, ultrapassam a última fronteira da humanidade e adentram no campo de uma violência produtora de outras possibilidades de ser. A negação, ou pelo menos a desconfiança diante destes conceitos fechados, pode oportunizar a compreensão de formas distintas de engendrar a subjetividade substituindo as tradicionais hierarquias imobilizantes pela diferença como instrumento privilegiado de leitura, representação e construção de si.

\section{REFERÊNCIAS}

\section{Bibliográficas:}

BENJAMIN, Walter. A obra de arte na era de sua reprodutibilidade técnica [primeira versão]. In: Id. Obras escolhidas I: Magia e técnica, arte e política. Trad. Sérgio Paulo Rouanet. São Paulo: Brasiliense, 1985.

BIRMAN, Joel. Desconstrução da filosofia do sujeito. In: Id. Entre o cuidado e o saber de si: sobre Foucault e a psicanálise. Rio de Janeiro: Relume-Dumará, 2000.

CAMUS, Albert. O estrangeiro. Trad. Valerie Rumjanek. 3. ed. Rio de Janeiro: Record, 1957.

DELEUZE, Gilles; GUATARRI, Félix. Mil platôs - capitalismo e esquizofrenia. Trad. Aurélio Neto e Celia Costa. Rio de Janeiro: Ed. 34, 1995. 
DERRIDA, Jacques. A escritura e a diferença. Trad. Maria Beatriz Marques Nizza da Silva. São Paulo: Perspectiva, 2002. Col. Debates.

DERRIDA, Jacques. O animal que logo sou. São Paulo: UNESP, 2002.

DUFOURMANTELLE, Anne. Anne Dufourmantelle convida Jacques Derrida a falar da hospitalidade. Trad. Antonio Romane. São Paulo: Escuta, 2003.

FREUD, Sigmund. Projeto para uma psicologia científica - 1895. Vol. 1. In: Id. Publicações pré-psicanalíticas e esboços inéditos. Edição Standart Brasileira das Obras Psicológicas Completas de Sigmund Freud. Rio de Janeiro: Imago, 1969.

FOUCAULT, Michel. A escrita de si (1983). In: Id. Ética, sexualidade e política. Manoel Barros da Motta (Org.). Trad. Elisa Monteiro e Inês Barbosa. Rio de Janeiro: Forense Universitária, 2004.

FOUCAULT, Michel. Nietszche, Freud e Marx (1967). In: Id. Arqueologia das ciências e história dos sistemas de pensamento. Manoel Barros da Motta (Org.). Trad. Elisa Monteiro e Inês Barbosa. Rio de Janeiro: Forense Universitária, 2005.

FOUCAULT, Michel. Nascimento da biopolítica. São Paulo: Martins Fontes, 2008.

FOUCAULT, Michel. O que é o autor? Lisboa: Veja, 1992.

HALL, Stuart. Nascimento e morte do sujeito moderno. In: Id. A identidade cultural na pósmodernidade. Trad. Tomaz Tadeu da Silva e Guacira Lopes Louro. Rio de Janeiro: DP\&A, 1999.

VERNANT, Pierre; VIDAL-NAQUET, P. Mito e tragédia na Grécia Antiga. São Paulo: Livraria Duas Cidades, 1977.

SILVA, Thomaz Tadeu da. A produção social da identidade e da diferença. In: Id. (Org.). Identidade e diferença: a perspectiva dos Estudos Culturais. Rio de Janeiro: Vozes, 2007.

\section{Fílmicas:}

Carandiru. Hector Babenco. Roteiro: Vítor Navas e Fernando Bonassi. Elenco: Luiz Carlos Vasconcelos, Milton Gonçalves, Rodrigo Santoro, Lázaro Ramos, Caio Blat. Brasil, 2003.

Cidade Baixa. Sérgio Machado. Roteiro: Karim Ainouz e Sérgio Machado. Elenco: Alice Braga, Lázaro Ramos, Wagner Moura, Harildo Deda. Brasil, 2005.

Cidade de Deus. Fernando Meirelles e Kátia Lund. Roteiro Bráulio Mantovani. Elenco: Matheus Nachtergaele, Seu Jorge, Alexandre Rodrigues, Leandro Firmino da Hora. Brasil, 2002.

Ó paí, ó. Monique Gardenberg. Elenco: Lázaro Ramos, Stênio Garcia, Wagner Moura, Luciana Souza. Brasil,2007.

Salve geral. Sergio Rezende. Roteiro: Sergio Rezende e Patrícia Andrade. Elenco: Andrea Beltrão, Lee Thalor, Denise Weinberg, Bruno Perillo. Brasil,2009.

Tropa de Elite. José Padilha Roteiro: José Padilha, Bráulio Mantovani, Rodrigo Pimentel. Elenco: Wagner Moura, Caio Junqueira, André Ramiro, Fernanda Machado, Fernanda de Freitas, Maria Ribeiro, Milhem Cortaz. Brasil, 2007.

Última parada - 174. Bruno Barreto. Roteiro: Bráulio Mantovani. Elenco: Michel Gomes, André Ramiro, Cris Vianna, Marcello Melo Jr., Gabriela Luiz, Anna Cotrim, Tay Lopez, Douglas Silva, Rafael Logan. Brasil, 2008. 
